\title{
9 \\ Life in the Rice Fields
}

Quin was always telling the kids and me about how he spent much of his early childhood in his grandmother's village of Bercoli, a small rural Waima'a-speaking village in the foothills of the central ranges about 40 minutes south of Baucau town. Like Baucau, it features dryland savannah in its upper reaches and spring-fed groves and rice terraces in its lower reaches. His memories of the rice planting and harvest seasons are of long periods spent working in the fields with extended family members, of the paddy being trampled by buffalo and horses, and of lots of adventures slingshotting birds for meaty snacks. During the harvest, the days would merge with nights spent out in the rice houses, threshing the rice stalks by foot in large family groups. It is never the hard labour that Quin remarks on. Rather, he recounts the nights spent dancing, singing and telling stories to accompany the work of threshing, the sleeping out together in the rice houses and the rice field meals prepared by his aunties. Quin wanted Madalena and Zeca to experience that life, too.

By the time of our arrival in May, the rice harvest was in full swing. The rains had been good in February and March, but they had disappeared in April and most of the rain-fed rice fields had withered. Meanwhile, the rice fed by springs was doing relatively well. The valley had transitioned from verdant green to a thick golden carpet. People were expecting a good harvest. On the day we reached Bercoli, no one was home: they were all down in the lower fields in the valley. As we walked from the road down through the already harvested sections of the fields, we noticed many bamboo lengths leaning on rocks and tiny fireplaces in the corners of the 
fields. Each of these offerings signalled that the ceremonies had been carried out to seek ancestral permission for the harvest of the particular field. In the areas where the harvest was complete, more elaborate ritual signs signalled another set of rituals was complete.

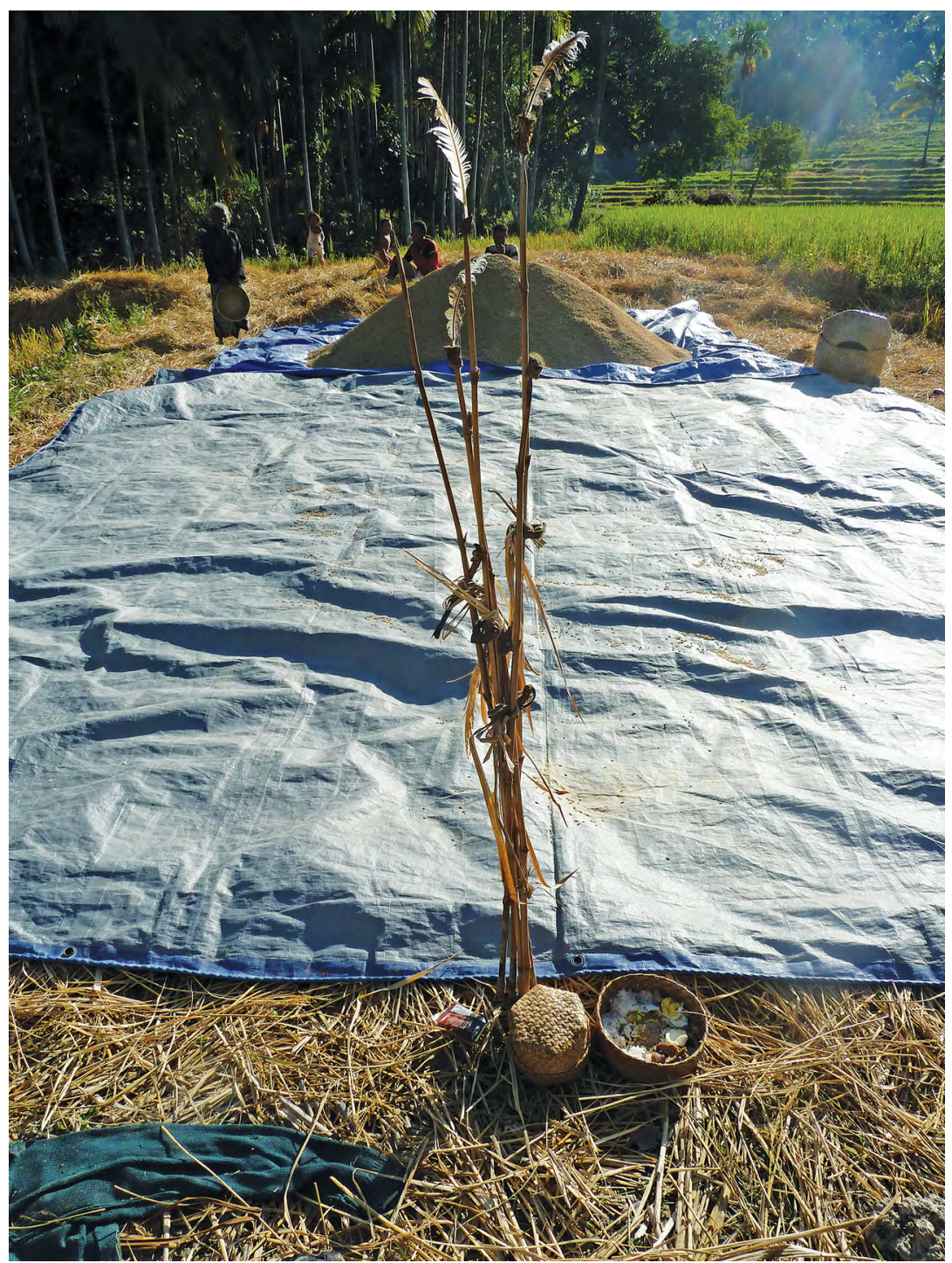

Photo 36: Rice harvest ritual offering. 
Every rice field area—referred to as an ulu (head)—has its own history associated with ancestors and ceremonies. While the repertoire of ceremonies is broadly similar, the ancestral invocations attached to each area vary. The first ceremony required is the pre-harvest ceremony. In the Bercoli valley, this involves a chicken, eggs and a portion of the previous year's rice offered in bamboo lengths to the custodians, the ancestors of the fields and the springs that water the fields. Another ceremony must be carried out prior to the rice being carried home. The final ceremony of the harvest period is the saur haree (new rice consecration ceremony), in which rice is first offered to the ancestors at the origin house site in exchange for blessings on the health of all those involved in the harvest and for prosperity in the coming agricultural year. Until this ceremony is complete, the senior representatives of each house may not consume the new rice.

We made our way down the slippery, mud-filled paths between the rice terraces to find Quin's uncles and male cousins busily threshing their newly harvested rice. In the rice house next to the field, a woman was cooking rice and stew for the workers. Quin's cousin Noyti and her neighbour Luciana worked nearby and had nearly finished harvesting an area that belonged to other family members. Noyti and Luciana are sharecroppers in another area of rice across the valley. These fields, in a stunning location just below the main springs of Wai Daba and Ocabai and facing the mountains of Matebian, had been bequeathed to Noyti by her father. The women told us that their fields would not be ready for harvest for another month and so we promised to come back to help them with the harvest. Unlike in Atambua, where contract labour is now predominantly used for the rice planting and harvest, in Bercoli most rice is produced for family consumption and the rice is harvested by family and neighbourhood groupings.

Before leaving, we shared lunch with the women in the rice house. The food was good, but the rice was not as nutty and tasty as I remembered from past visits to the village. The reddish-brown tinge of the bran was notably absent from the grain. Noyti and Luciana concurred about the reduced quality and taste of the local rice. Even just a few years ago, locally produced rice was more flavoursome and, when consumed with local vegetables and chilli or simply as a rice porridge, each mouthful was like a vitamin hit. Now, if the rice is cooked over an open fire, some of this flavour is retained, but the rice varieties and growing practices themselves have changed. 


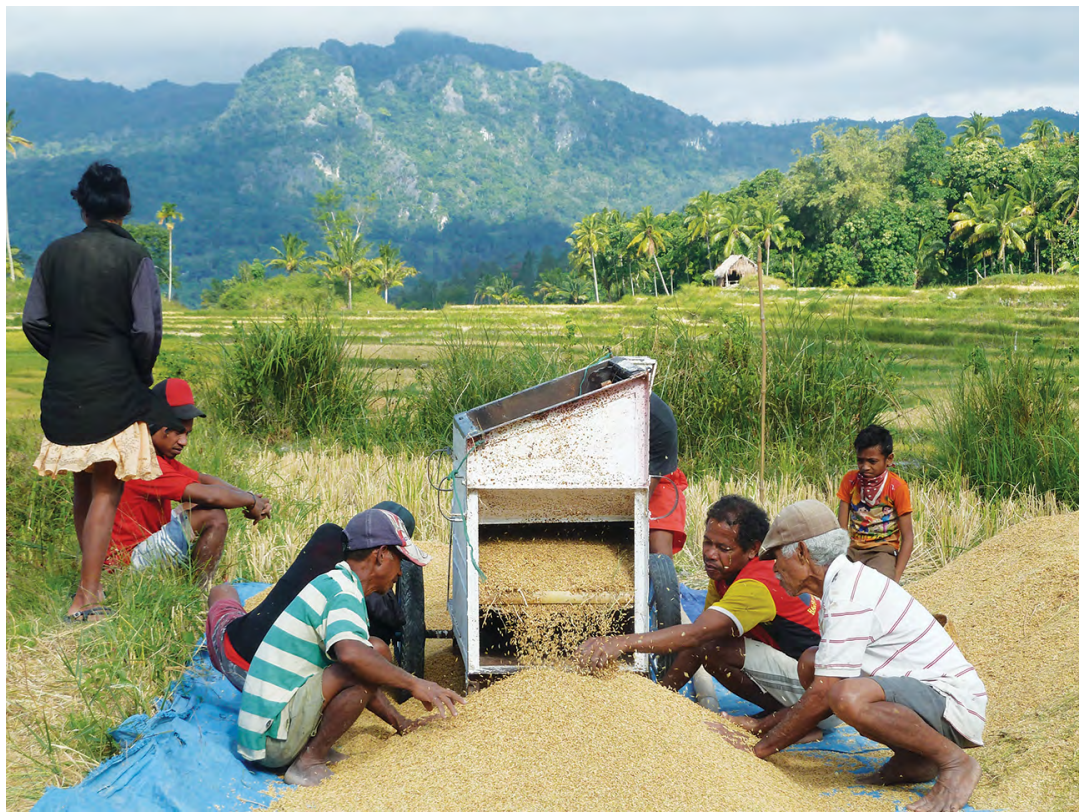

\section{Photo 37: Wai Daba rice fields with Mt Ariana in background (Old Man at right).}

The Timorese government and donor agencies have worked hard to introduce new improved, higher yielding and longer lasting seed varieties that have been distributed across the country for free. But increased productivity seems to have come at the cost of flavour and the nutritional value of the grains. With the increased use of mechanised rice husking in the final stage of grain preparation, the bran of the rice is completely polished away, further reducing taste and nutrients. This is especially noticeable in lean times, when a meal may consist only of rice and a chilli salsa. In the past, even this was filling and delicious.

While recognising that the new varieties and processes save labour time and obtain higher yields, Noyti and Luciana lamented the changes. They pointed out that younger generations of Timorese no longer know how to select, and save, the diversity of seeds once tailored by farmers for local agricultural production. Nor do younger generations know as much about the stages needed to properly dry out the grains in the sun or how to husk the rice by hand. In many cases, younger urban Timorese do not even know how to clean and prepare rice for cooking. 'There is no going back,' Noyti and Luciana said. 
Two weeks later, we returned to Bercoli to help out with the remainder of the harvest. Noyti's fields were still not ready, so we began work in the lower fields, an area we soon understood as the centre of power in the valley. This area, known as Kai Bo'o, contained fields shared between the siblings of Quin's uncle and Noyti's father, Elisio. He is the senior ritual leader for the valley and the senior customary law man for the entire village, frequently consulted on issues arising in both its savannah and valley environments. In Kai Bo'o, most of the siblings had already harvested their rice and completed their ceremonies required to carry it home. Yet all of their rice was still stored out in the fields. Before their rice could be taken home, cultural injunctions require that they must wait for Tiu Elisio's rice harvest and for the completion of his ceremonies.

Tiu Elisio-often referred to simply as the Old Man-is the customary head of the Wai Daba house. I first met him when I travelled to East Timor, just after independence, in the year 2000. Quin's younger sister, Mena, had been a good friend of Marcia's and mine in Darwin and, as she happened to be visiting Timor at the same time, we made a trip out from Dili to Baucau and Bercoli. (This was a year before I met Quin: he had called me up when he heard his sister's friend had moved to Melbourne.) Because of that first early meeting, the Old Man takes credit for our marriage and loves nothing more than telling people it was only because Quin married me that he has now returned from Australia to the village. Despite his advanced years, the Old Man retains his handsome features and sharp, sometimes cutting, wit. While never formally schooled, he is intensely intellectual and political. When he has the chance, he talks of the region's history and politics, often lamenting what his life could have been if the Portuguese were not so selective about who they allowed to have an education. He would have loved to become a national political leader and steer the direction of the new nation. Once, as we sat together chatting on the back porch, he said: 'If I had been educated, I would have married a malae.' While this statement was perhaps referring to the utility or power of malae (which, interestingly, can mean foreigners, outsiders or nature spirits), I was not exactly sure about its implications, but his wife did not seem perturbed.

The house of Wai Daba, to which Quin's paternal grandmother also belonged, is the custodial house for the valley's main spring of the same name. In the past, the rice fields in the entire valley belonged to Wai Daba. At times when the local population was low, the ancestors of the Wai Daba house made agreements with outside kingdoms to send labourers 
to the area to help farm or tend lands. Many of the fields in the valley are still farmed by the descendants of these 'newcomer' families, some of whom married into the house of Wai Daba. As a result, many more families are now considered members of the house. But marital relations and land allocations are always historically complex and sensitive issues that involve a range of context-specific rights and obligations. The extent of these 'newcomer' rights in the land and resources is a topic of ongoing social negotiation, and periodic dispute.

One night, when we were staying at the Old Man's house on the main road, we discussed local land politics over dinner with him and other family members. Once most families had lived down in the valley or up on the savannah, but, during the Indonesian occupation, people were forced to relocate along the roadside, and most people remain there. Due to these often-forced migrations, there is a further degree of contestation in the village between those who have more recently come to farm on the land of others and those who assert ancestral ownership or use rights to the same land. Senior men and women still know these local histories. As a result of these elders' social knowledge and cultural capital, it seemed that simmering tensions in the village were largely kept at bay. But both elders and the younger people worried that if a new generation of customary leaders does not emerge to learn and pay close attention to these histories, unentitled others may usurp the land when the elders are gone.

At some point in our conversation, the Old Man asked me to help him find 'the book'. The location of this elusive book had been a frequent topic of discussion and it was not the first time he had brought it up with me. Indeed, it is a frequent topic of conversation and its loss an ongoing lament for the Old Man, as he explained to me years ago:

What is important here is water. Our forebears were able to produce fields, rice and plantations because of this water. Our rice fields are old. In monarchical times before the Portuguese arrived, we already had them. We had no buffalo or horses; we would prepare the fields by dragging rocks through them. We would make a place and tie a rope to a piece of limestone and drag it around to make the soil muddy. There were no animals. And there was only a small amount of rice fields. These original rice fields were all named. 
When the Portuguese arrived in the early twentieth century these fields were recorded in a book of tax records, but when our sacred house was burnt down [in the Indonesian era] that book was lost. In the past, my aunt, and Quin's grandmother, married a Chinese merchant in Baucau. She would pay the tax for this land. Her husband also worked with the Portuguese administrators and he would collect the tax for them.

The Portuguese sent only the children of the rulers they aligned themselves with to school-this was a kind of politics. If this hadn't been the case, we would all be smart by now. Bercoli is the heart of the Waima' lands which stretched from here to the top of Matebian and across to Vemasse. While now these lands are largely dominated by the Makasae, it was the Portuguese that carved up the land.

In the Old Man's account, ancestral connections to the land and its waters are paramount, but it is also apparent that for him colonial-era taxation records are just as legitimate a witness to this reality. According to the Old Man, the book of records is important proof of land ownership in the context of disputes over rights to particular rice fields. The book, together with oral histories, proves the Old Man's contention that the descendants of newcomer houses were invited into the area and given rights based on land use, not ownership.

So, again, the Old Man asked me about the book. Had I been to Portugal to look for it yet? Had I made enquiries? I confessed sheepishly that I haven't yet had the opportunity; I don't speak Portuguese, so I needed to find someone who could help with the task. He was clearly disappointed. He wondered whether it might be in Macau. I could look there. He had heard from the Bishop of Baucau that many records from Baucau were kept in the Portuguese government archives in Macau. I solemnly promised that I hoped one day to be able to go to both places and investigate for him.

The following day, the Old Man's sister, Tia Martina, was to hold the ceremony to prepare her rice for carrying home. The day began with a ceremonial sacrifice of a chicken at the vent-like crevice hidden in the forest beside the Kai Bo'o fields. The chicken and the rice were cooked inside bamboo and some of it carried down deep into the crevice where if it was offered to the cave custodian with ancestral prayers. The rest of the chicken was taken to the $u l u$ of the rice fields where the threshed rice lay 
in a huge pile on a side hillock. The chicken was arranged on a makeshift altar and laid out with baskets of rice containing eggs, betel leaves and areca palm nut. Here, more prayers were incanted. A goat had been killed but this was not part of the ceremony- 'it's just for eating', said one of the uncles. This goat was a Timorese goat (bibi Timor), whereas in these fields only foreign goats (bibi malae) could be used for ceremony.

Later in the afternoon it was time for the threshed rice to be moved from the hillock into large storage bags. We were instructed by an uncle not to leave the ceremony area until it was finished and we had all eaten together. This is lulik or ancestral law. The uncle also told us that women may not enter the men's-only area while the rice-bagging ceremony was being carried out. Madalena and I passed the time with the other women and girls in a makeshift kitchen area. Tia Martina stood by the altar replete with offerings, periodically reaching into the baskets and taking out small handfuls of rice, which she sprinkled on the ground to feed the custodians of the area. She continued the feeding until the rice-bagging ceremony was over.

Quin filmed the ceremony up on the hillock and shared it with me. There was no prohibition on women viewing the ceremony, but, according to the culture of Wai Daba, they could not be physically present in the space. The ceremony began with an uncle, Tiu Vicente, placing several large baskets on top of the pile of threshed rice at the same time as thrusting a machete into its middle. The machete symbolises security, and the baskets delineated the area around which that security is extended. Through this ceremony, Tia Martina and her brothers who assist her were seeking the security of a prosperous rice-growing season the following year-their collective acts implored the ancestors to ensure that pests, extreme weather events or malign people do not attack the rice. Tiu Vicente prayed to the ancestors and began to fill the baskets with rice. The younger men then helped carry it over to the larger rice bag. Everyone was very keen to count how much rice had been harvested. In all, 59 baskets had been amassed, a number more than the previous year. The two large storage bags of rice, each holding approximately 30 baskets, hold a potential market value of around US\$4,000. 


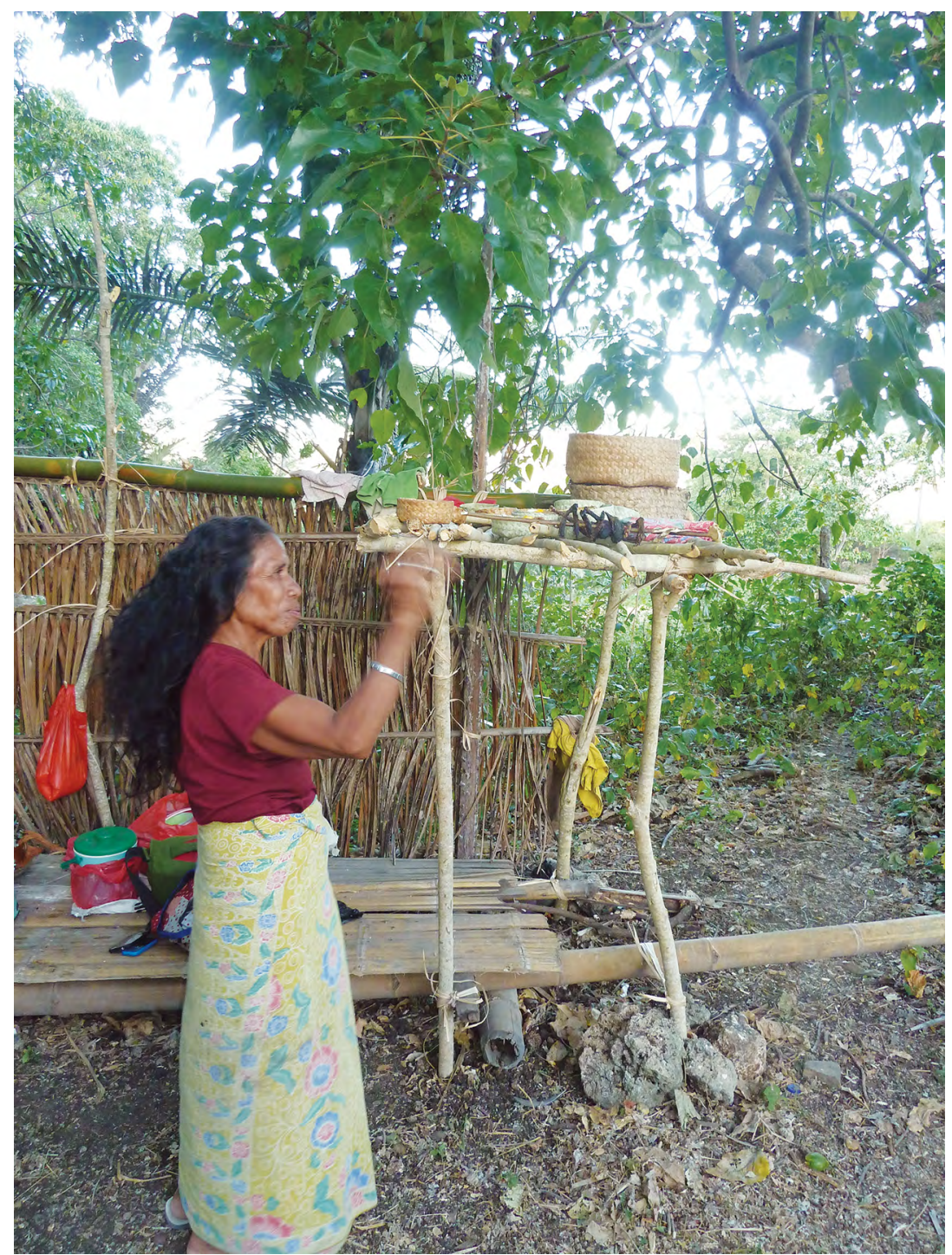

Photo 38: Tia Martina carries out her part of the rice harvest offering.

Upon completion of the rice-bagging ceremony, the space was again opened up again for all to enter. The kids charged with glee up the hillock, beneath which huge piles of threshed rice stalks lay. They were free to roll, trample and bounce in the piles of hay to their hearts' content. Madalena and Zeca could not believe their luck; it was their first such experience of an event that would become a highlight over the coming weeks of the 
harvest. Rice stalk piles became some sort of surreal pop-up play centre. As the sun set, we looked up and noticed the forest's bat colonies on the move overhead. Bats, too, are ancestors.

Once the play was over, we were all called back to the cooking space. It was time to eat together. Everyone shared in the chicken, the goat, rice and eggs. Finally, we were each given a piece of betel leaf and nut as a blessing. It was late and very dark when we packed the kids in the car to return home. Our offer of a lift was declined by the Old Man. He walked home through the forest and rice fields alone-no doubt, checking the land for all sorts of propitious signs.

With each day in the fields I came to understand more about the significance and extent of these harvest ceremonies. At the same time, I had to accept that many aspects of this ritual world were out of bounds for me, now that I was actively participating in the family harvest. Back in 2013, the Old Man had allowed me to participate in and film the final new rice ceremony at the Wai Daba spring. Back then, my status as an academic (or journalist, as the Old Man prefers to call me) seemingly overrode the prohibition on women. But this time, he had stated, without further explanation, that I could not participate. There was an irony here: now I was an insider, I must play by the rules. In this case, the rules dictated that I sit on the outer. While the view from the inside is infinitely richer, it does not come without consequences for one's individual freedom.

Day by day, we came to appreciate the intricacies and seriousness of observing the customs of this world. One morning over breakfast, we learned more about the various harvest prohibitions such as a ban on taking peanuts and certain other foods into the fields. Once the Old Man told us about this, we quickly stopped the kids snacking on our stores of local peanuts (at least in the fields), but we had no idea of the reasons for this rule. 'Well,' said a cousin who had dropped in to visit, 'we must be very careful what we do in the valley'. He went on to casually describe the custodian of the rice fields as a very aggressive seven-headed snake. Even the removal of large rocks from the fields would cause him to retaliate. If he did, the Old Man, as the living human custodian of the site, would become sick straightaway. Newcomers to the valley must be especially careful of these custodians who are quick to attack. The kids' eyes widened. 'It's okay,' Noyti reassured us, 'the land knows who you all are.' 
When we were harvesting rice near another spring, Wai Te, Quin and Zeca tried to sneak off to explore the area. They were warned to be very cautious. In hushed tones, we were told that, sometime ago, a being had emerged from the spring appearing to people in different forms. Sometimes it was a snake; another time it was a boat whose emergence created so much wind that the nearby candlenut trees toppled over. An unidentified white car (the kind driven by powerful people: foreign NGO workers, government people or clergy) had also been seen parked in the area. Wai Te was rumoured to host an entire city beneath its waters.

Each day as we laboured under the hot sun in the fields, we passed the time by gossiping about local life and happenings. Madalena and Zeca would help for a while, somehow avoiding slicing their fingers and feet with the deadly sharp rice sickles. After a while, they would wander off with their younger cousins to play or pick forest fruits. When Noyti and Luciana's older kids finished school each day around midday, they would join us and help in the fields, as would the children of whoever else was in the fields. Some children were more helpful than others, but, as a rule, the whole family helped out at harvest time. Some would occasionally climb the coconut palms fringing the fields, throwing down young coconuts that we would cut open and drink thirstily.

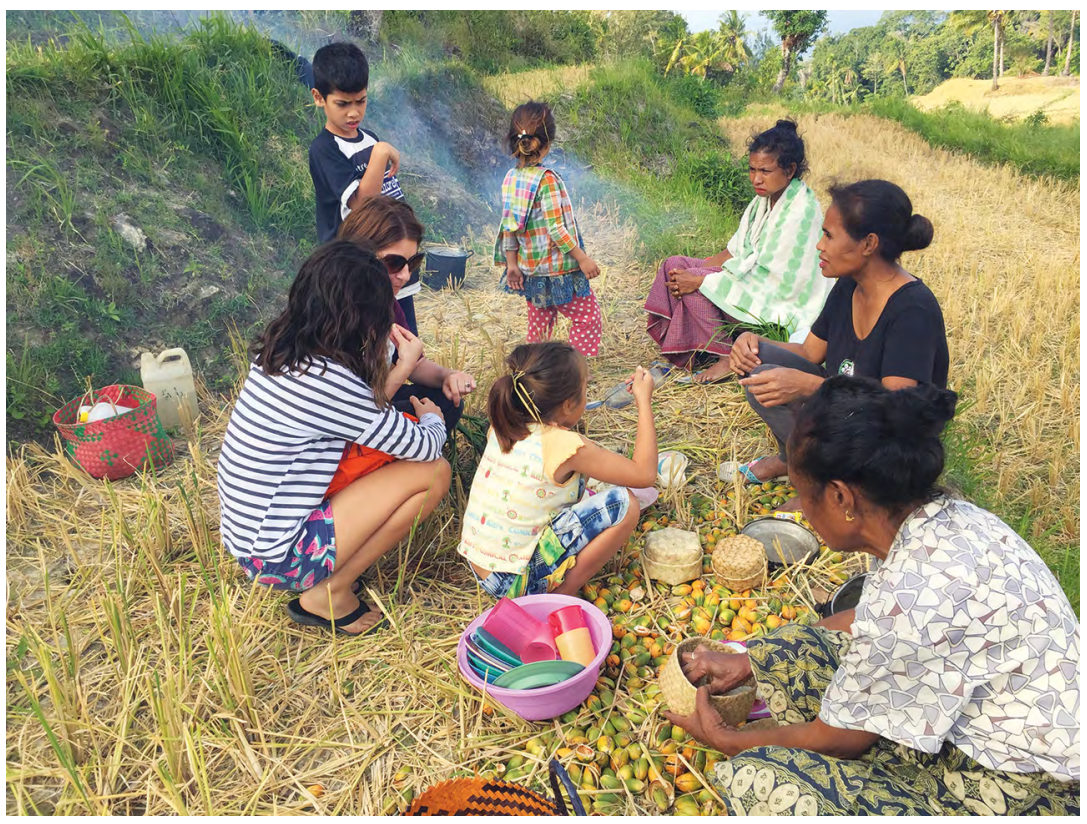

Photo 39: Lunch in Noyti's rice fields. 
When it was just the women and me in the fields, the conversation would be in Waima'a, which I couldn't understand. But, if Quin was there, or if I was a part of the conversation, they would switch to Tetum. One day, the women got onto the topic of childbirth. Tia Martina had eight grownup children. All except for her first child she had birthed at home alone. She said she preferred it that way. The women I was working alongside that day started talking about how absurd it was that doctors in Timor now advise women to stop physical work in the month or so prior to giving birth. They had all worked in the fields right up until the birth of each of their children. They said that work makes both mother and baby stronger, and that without physical labour women's bodies weaken and the babies are not moved along. They reasoned that this was why young Timorese women are increasingly experiencing complications in pregnancy and a higher frequency of caesarean deliveries. 'You've got to be careful of going to the hospital,' they said. 'Babies can die there.'

Another frequent topic of discussion was marriage and divorce. We talked about who was betrothed to whom and what was being exchanged in the process. We would spend hours talking about the various divorce proceedings underway and the attempts of families to reconcile outside of the court. The women worried that the new civil laws concerning marriage had done women a disservice, leading men to think it was their right to walk out and leave the women to look after the kids.

Medicinal plants were another frequent topic, often at my instigation. Sometimes we would come across a small plant or tree by the side of the fields as we cut the rice or took a rest. If I asked what it was, invariably the plant would turn out to have a medicinal use. Its leaves or bark or sap would be useful for certain known remedies. But the knowledge was clearly specialised and person-specific. One day I asked Noyti about a particular weedy grass common in the area we were working. 'What's this?' I asked. 'Oh, that's just grass,' she said. 'At least for me. For someone else it might have a use.'

Slowly I came to learn about women's deep knowledge of plants and their uses, how to collect them and how to prepare them. It always included a vast, but very personal, array of food and medicinal plants. Frequently, on our walks to the fields, the women would pick a particular plant to take home and prepare to treat one of their children or another family member. I recalled that a year or two earlier, when I had just begun researching health and healing and had asked these same women if they had medicinal 
expertise they would like to share, they would always decline or downplay their knowledge. I was usually sent off to interview men. I was coming to realise that this was knowledge and practice you had to learn by doing. Indeed, our own children's ailments, various rashes, cuts, scratches and bumps were typically the starting point for an intervention and visit to the forest pharmacopeia. Even our young nieces knew where to source the plants and how to prepare them to treat everyday ailments. Very often, these children were our doctors.

I noticed, too, how the women were in constant communication with the spiritual realm-even though they might deny it publicly. While formal ceremonies are usually men's business, talking with the ancestors or looking for ancestral signs is just as much women's as men's business. One day, as we chatted away in the fields and rain clouds began to loom on the horizon, one of the older women immediately cupped her hand to her mouth and blew in the air loudly. She looked at me with a smile. 'I am just letting the ancestors know to stay away-not to come yet-we are still harvesting the rice.' It seemed to work. The clouds soon cleared.

When we had finished cutting each area, we would switch gears for the next phase of the harvest. The younger men of the households would then start their labour. Their work involved collecting the harvested bushels of rice, tying them together and heaving them up to the area where the rice would be threshed using the valley's portable machine thresher. Almost gone are the days when the threshing was done by human foot or horse's hooves. What the machine can do in one day would have taken at least a week of work in the past.

In this phase of the harvest, it is the women's task to cook for the men, on site in the rice house or at home in the kitchen. They carried the prepared foods and hot coffee in large thermoses down to the fields on their heads (or, in my case, more awkwardly tucked under my arm). At this stage, women do much less of the hard, physical labour, although the cooking is still laborious and there is always the washing and looking after kids. Once the food had been prepared and delivered, the women would sit and chat in the rice house, catch up on happenings and gossip in a leisurely style. I enjoyed the chance to relax and listen, although I didn't understand much of what was said, let alone the hilarious jokes that would have them in stitches. 


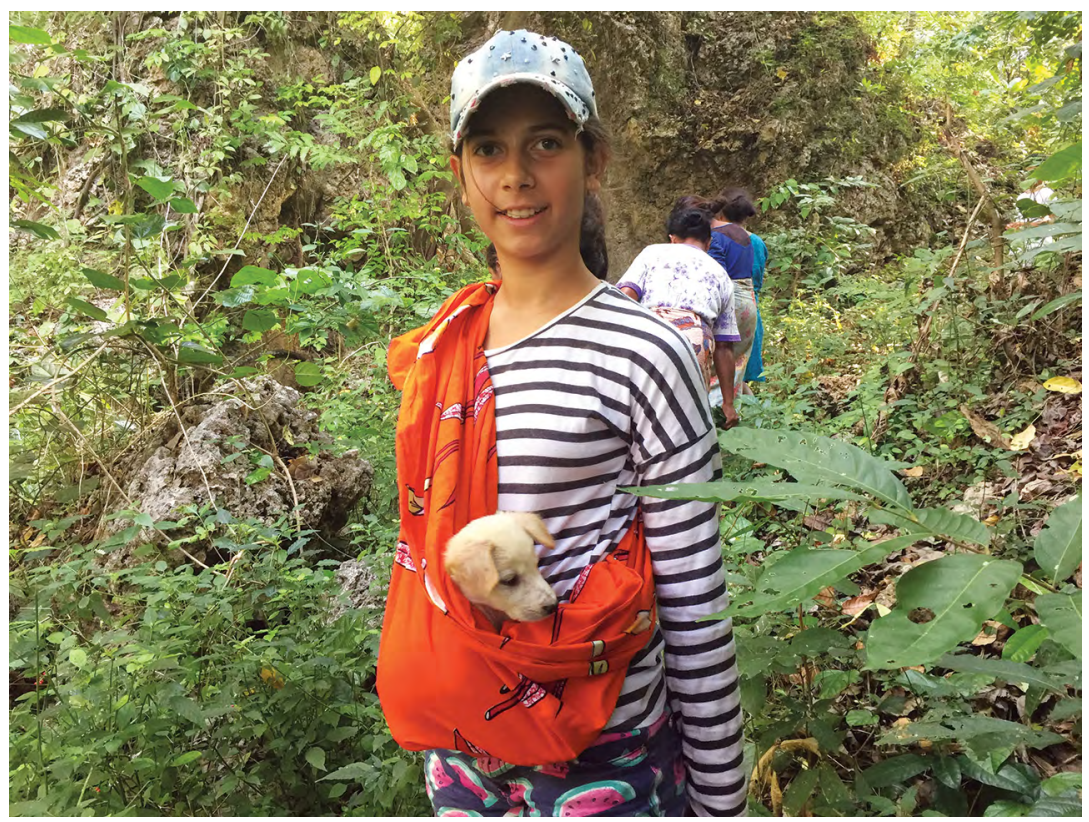

\section{Photo 40: Madalena and Golden.}

It was on one of these days that Zeca and Madalena received an unexpected gift. Sitting with the women under the afternoon shade of the rice house, one of the local teachers arrived holding a tiny white puppy under his arm. 'This is for them,' he said, pointing to the children. The puppy's mother, a scrawny white dog that belonged to the teacher, was milling about the fields where the rest of the teacher's family was also working. The mother dog had long since given up on the puppy. Apparently, one day when it had been out roaming the fields with its mother and siblings, it had fallen in a deep, dry, irrigation ditch and had not been able to get out. Some villagers living nearby had rescued it and taken care of it for several weeks. Now the teacher had reclaimed it for Zeca and Madalena. They had never had a puppy of their own and their eyes widened in disbelief and excitement. Later, when we were walking home, we fashioned a sarong like a baby sling around Madalena's shoulder. She carried the puppy in the sling back through the fields, proudly announcing to everyone that its name was Golden, after the colour of its ears. I sensed that the teacher and his family (descendants of 'newcomers' to the valley) were also quietly very pleased with this outcome. Golden was a gift who wove our family increasingly closer to the valley, perhaps subtly making us a little beholden to them. 
While we were busy with the puppy, the men worked intensely, deftly operating the thresher to complete the task. Observing them, I was impressed by the highly choreographed ways in which each man or young boy would work and cooperate as part of a team. There was still a lot of manual assistance work to be done despite the use of the mechanised thresher. They appeared to effortlessly share and change tasks as needed, with some dropping out or slowing pace now and then, later coming back into the flow of work. The atmosphere was lighthearted. People seemed ever ready to share a joke, although, at certain points, when banter turned to national politics, merciless teasing between political rivals could create flashpoints of anger.

During this 2018 harvest, many of the younger men complained that they were too tired to work. None of them had slept much over the last month, instead gathering together each night to watch the football World Cup broadcast from Russia. The matriarch of the valley, Quin's elderly aunt Tia Brigita (or the Old Lady, as we called her), had no sympathy. She told them that in the past when people threshed rice by foot, people would be similarly deprived of sleep! Evenings would be full of dance, song, storytelling and collective trampling. Now satellite television was the culprit. Either way, there was work to be done!

Despite the goodwill, there was growing unease among the harvesters over what was to be done with this year's bumper harvest. Political unrest in the capital meant that for two rice-growing seasons in a row the government had not come as promised to purchase rice from the newly built rice stores in the valley. Despite a program known as 'povu kuda, governu sosa' ('the people grow crops, the government buys'), government purchasers had not materialised. The people had duly changed their riceproduction practices by switching to the higher yielding varieties, but now they could not sell their surplus. Similar situations across the country led to the coining of another more popular slogan, 'povu kuda, governu sae' ('the people are the horses, the government ride them'). (Kuda can translate either as 'to grow crops' or as 'horse'.)

Just as economically profitable as rice crops, but more secure, was the sale of pigs. As soon as they were old enough, each of Noyti's five daughters had taken on the daily chores of helping their grandmother raise pigs in wood-and-thatch sties built at a distance behind the house. Raising pigs is laborious: the children's daily tasks involved the collection and cooking of substantial foodstuffs including husked rice bran, yams, coconut meat 
and household scraps. After working in the rice fields each afternoon, these children would also spend time with their mother and grandmother picking up old coconuts from the ground in the coconut groves, cleaving them open with a machete and digging out their hard flesh with knives. After also collecting bundles of firewood for cooking, they would bag the coconut meat and carry it with the wood on their heads back home.

When a pig reaches maturity, usually after seven or so years, it will be sold. The need for pigs in marriage exchange rituals means there are always plenty of buyers. The money raised from each sale, up to approximately US $\$ 800$, is 'banked' for their children's future education. One day when we arrived home from the fields, we found one of Noyti's teenage daughters, Asandi, near the empty sty choking back tears. The pig had just been sold and its departure had affected her deeply. Through seven years of daily care, she had developed a great affection for the animal. She also knew, however, that its sale was her chance for a future education.

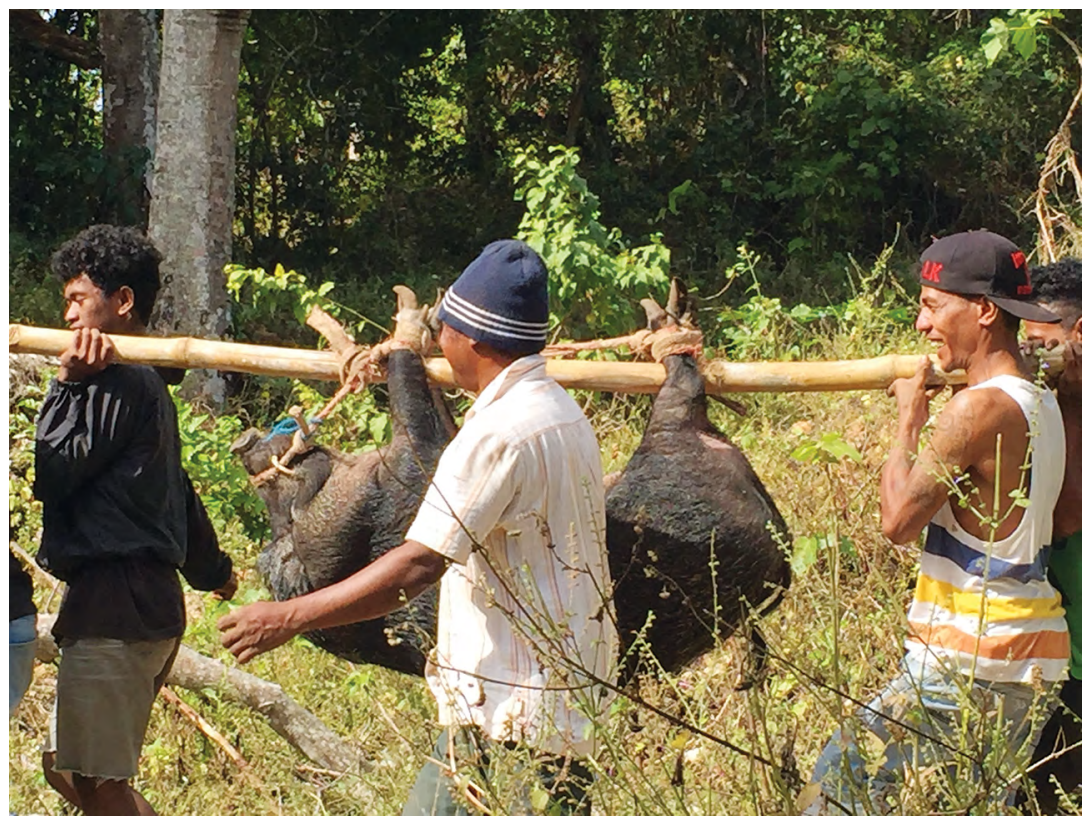

Photo 41: The purchased pig. 
Towards the end of our time in the village, we killed a goat to celebrate Quin's birthday and invited our extended family from Bercoli and Baucau to attend a party. When Quin went with the Old Man to source the goat from the plateau above the village, the goat farmer resolutely refused Quin's payment. He remembered Quin's father having helped him during the resistance times and he wanted to honour that debt. At the same time as honouring a debt, the gesture created a new relationship. We were now obligated to the farmer, and it was understood that there would be plenty of time for us to reciprocate.

The goat meat and rice were cooked on an outdoor fire in bamboo lengths. Quin's older brother, Domingos, came from Baucau town to marinate the meat. Like Quin's father, and all his sons, Domingos is a renowned cook. My cooking skills over the open fire were well known to be much more limited and I was not usually asked to do tasks beyond collecting water, cleaning and peeling vegetables and washing up. Even the way I collected firewood lacked the required skills of discernment. But on this occasion, I was called to the kitchen to procure a can of our emergency stores of tuna and open it for Luciana's husband, the man who had slaughtered and prepared the cuts of goat. Despite his hours of work, he was prohibited by custom from eating meat. I was pleased that, with this simple act, I could autonomously feed someone.

After a lengthy process of food preparation and cooking, the meal was finally ready. The cooked meat and rice were first taken into the house and placed on an offering table in the main room, to feed the ancestral spirits. All the guests knew that the ancestors would be angered if they did not receive their share. Madalena and her cousins were sent off around the neighbourhood to collect bougainvillea and other flowers to prepare garlands that would later be cast over the ancestral graves. At the end of the day, a small party of us took these flowers and boxes of candles to the graveyard a little way down the valley. Noyti and another cousin came with us because they knew to whom each grave belonged. This was the first time that Quin had been to this graveyard: in the past, when the children were younger, we had always stayed in town during our visits and we would visit the larger graveyard where Quin's parents are buried. I asked if we were going to these Bercoli graves as a matter of course for a birthday celebration or especially because Quin was newly 'returned' to the village. I was told that you would never have a celebration like this in the village without involving the ancestors-they would be insulted. The visit to the grave was a way of saying 'we are still together with you'. 
Life in these places is hard work. Returning home at the end of a long day in the fields, we would still need to pick fruit and vegetables from the gardens and forests along the way before preparing them and cooking for the large household, often without running water or electricity. While the electrical grid has now reached across the entire country, it is frequently unreliable. It almost felt as though the promise of electricity made it worse. Local households were now geared to a life dependent on power for pumping water and switching on lights. As a result, we were often caught off guard at night by last-minute power outages, left to function without the backup of kerosene lamps, rice cookers or stored drums of water. Still, we all preferred food cooked over the open fire. Despite the extra work it took to prepare, it was so much more flavoursome. We were especially pleased on these evenings when the Old Lady would make her signature dish, a kind of stir-fry of water taro stems freshly picked from the Wai Daba spring. This dish, which only she could cook successfully in our household, requires the utmost skill in execution. One wrong move, such as the use of metal utensils, and the delicious meaty stems would leave the insides of our mouths and throats itchy for hours. In contrast, the Old Lady's hands, they all said, were sweet (liman midar). Try as he might, Quin couldn't replicate her method.

We had come to the village hoping to give the kids an experience of rural life. We left immersed in another Timorese world. If only briefly, we lived a life wherein the hold of lulik_-of the ancestors—is unquestioned. Their presence permeates the mind, the body, everyday relationships, practices and interactions. During our time in Bercoli, we were also made aware of the many current and potential disputes over rights to land and resources. Big questions loom over future pathways of inheritance and land use. But what had become clear was the depth of common concern to honour and respect their ancestors. And what flows from this respect, in both directions between the living and the dead, is the strength of families and communities practised in the arts of living together, not apart. 
This text is taken from Island Encounters: Timor-Leste from the outside in, by Lisa Palmer, published 2021 by ANU Press, The Australian National University, Canberra, Australia.

doi.org/10.22459/IE.2021.09 